\title{
ANALISIS TEKNIKAL PERGERAKAN HARGA SAHAM DENGAN MENGGUNAKAN INDIKATOR STOCHASTIC OSCILLATOR DAN WEIGHTED MOVING AVERAGE
}

\author{
NUR ALVIYANIL 'IZZAH \\ DINA YENI MARTIA* \\ MARIA IMACULATA \\ MOH IQBAL HIDAYATULLAH \\ ANDHIKA BAGUS PRADANA \\ DIYAH AYU SETIYANI \\ ENES SAPURI \\ Politeknik Negeri Semarang \\ *dinayenimartia@polines.ac.id
}

\begin{abstract}
Investments in the stock market are closely related to the price movement risk. Investors used technical analysis to minimize the risk caused by changes in stock prices. Hence, investors get the right decision to buy or sell the stocks. Weighted Moving Average and Stochastic Oscillator are technical analysis indicators that investors often use due to their ease and accuracy predictions. This study combines the Stochastic Oscillator and Weight Moving Average (WMA) indicators to predict stock price movements in various industrial sectors during the 2015 to 2019 period and the first semester of the 2020 covid-19 pandemic outbreak in Indonesia. This combination aims to provide better predictive results by completing the weaknesses of each indicator. To provide recommendations for the right investment decisions for investors interested in investing their funds, especially in various industrial sectors. Using the combination of WMA and SI indicator charts from the investing.com website resulting in a better prediction of the right time to buy or sell stocks in various industry sectors. While the shares of SCCO, INDR, INDS appear stable during 2020, the movement of KLBM and KLBI's share prices seems to be affected by the Covid-19 pandemic in Indonesia.
\end{abstract}

Keywords: technical analysis, Stochastic Oscillator, Weighted Moving Average, WMA

\begin{abstract}
Abstrak : Investasi di pasar saham sangat erat kaitannya dengan risiko perubahan harg. Analisa teknikal dapat digunakan investor untuk meminimalisir risiko yang disebabkan oleh perubahan harga saham sehingga mendapatkan keputusan rekomendasi beli atau jual dengan tepat. Weighted Moving Average dan Stochastic Oscillator merupakan indikator analisa teknikal yang sering digunakan oleh investor karena kemudahan dan keakuratan dalam prediksi. Penelitian ini mengkombinasikan indikator Stochastic Oscillator dan Weight Moving Average (WMA) untuk memprediksi pergerakan harga saham pada sector aneka industri selama periode 2015 sampai dengan 2019 dan juga semester pertama 2020 selama terjadinya wabah pandemic covid-19 di Indonesia. Kombinasi ini bertujuan memberikan hasil prediksi yang lebih baik dengan melengkapi dari kelemahan masingmasing indikator. Sehingga memberikan rekomendasi keputusan investasi yang tepat bagi investor yang tertarik untuk menanamkan dana nya terutama pada sektor aneka industri. Dengan menggunakan grafik indikator WMA dan SI dari website investing.com, diperoleh kesimpulan bahwa kombinasi kedua indikator memberikan prediksi dan konfirmasi yang cukup tepat dalam prediksi waktu yang tepat untuk membeli atau menjual saham pada sector aneka industri. Sementara saham SCCO, INDR, INDS tampak stabil selama tahun 2020, pergerakan harga saham KLBM dan KLBI terlihat terpengaruh atas pandemic covid-19 di Indonesia.
\end{abstract}

Kata kunci: analisis teknikal, Stochostic Oscillator, Weighted Moving Average, WMA 


\section{PENDAHULUAN}

Saat ini investasi di Indonesia berkembang cukup pesat, salah satunya investasi pada pasar saham. Berinvestasi pada saham memang cukup menggiurkan, pasalnya para investor akan mendapat keuntungan dengan cepat bahkan hanya dengan waktu satu hari, satu minggu, atau satu bulan, tergantung kondisi pasar saham. Keuntungan yang diperoleh juga bisa berkali lipat dari dana yang ditanamkan. Namun, apabila salah dalam perhitungan dan prediksi, investasi pada saham juga dapat merugikan investor dengan cepat pula. Sehingga investor perlu cara untuk mengantisipasi atau menghindari risiko yang mungkin terjadi.

Hasil survei pertama Olsen (1997) mengindikasikan bahwa risiko investasi merupakan konsep multidimensi dengan empat atribut utama yaitu kemungkinan kerugian yang sangat besar, kemungkinan pengembalian di bawah target, kemampuan mengendalikan kerugian, dan tingkat pengetahuan investor. Sementara, Jorion (2007) mengartian risiko sebagai volatilitas harga suatu asset. Risiko perubahan harga merupakan risiko yang sering terjadi pada investasi dalam pasar saham, sehingga perlu adanya antisipasi. Antisipasi risiko investasi di pasar saham selain dengan analisis fundamental yang dapat digunakan untuk mengetahui saham mana yang tepat untuk dibeli, juga perlu analisis teknikal guna mendapatkan rekomendasi kapan waktu untuk membeli atau menjual saham.

Analisis fundamental digunakan untuk mempelajari kondisi keuangan perusahaan dengan melihat laporan keuangan perusahaan tersebut. Salah satu analisis fundamental yang biasa digunakan untuk mengetahui harga saham berada pada posisi undervalued atau overvalued yaitu metode DCF (Discounted Cashflow Model) (Martia et al., 2018) dan FCFE (Free Cash Flow Equity) (Martia et al., 2020). Sedangkan, analisis teknikal digunakan untuk melihat pergerakan pasar seperti pergerakan harga dan volume perdagangan, serta untuk mengetahui kondisi pasar apakah dalam keadaan uptrend, downtrend, atau sideways (Nugraha, 2018).

Guna mendapatkan hasil prediksi untuk pengambilan keputusan membeli dan menjual saham yang lebih akurat, investor biasanya akan menggunakan kombinasi dari beberapa indikator analisis teknikal. Banyaknya variasi indikator teknikal yang dapat digunakan oleh investor tidak jarang memuat investor bimbang dalam membaca hasil grafik dari suatu indikator dengan tepat. Moving Average banyak digunakan oleh investor sebagai alat bantu analisa teknikal karena termasuk indikator paling sederhana dan mudah dipakai untuk menunjukkan suatu trend dari pergerakan harga saham (Wira, 2010). Namun Moving average merupakan lagging indikator yang cenderung lamban dalam memberikan sinyal entry. Sementara stochastic oscillator merupakan salah satu indikator leading yang banyak digunakan investor untuk menentukan kondisi jenuh jual dan jenuh beli di pasar saham (Yustian, et.al., 2019). Stochastic menunjukkan lokasi harga penutupan terakhir dengan membandingkan range harga terendah/tertinggi selama periode waktu tertentu (Wira, 2010).

Penelitian ini bertujuan untuk memberikan gambaran analisa pergerakan harga saham pada sector aneka industri selama periode 2015-2019 dengan menggunakan indikator stochastic oscillator dan WMA (Weighted Moving Average) untuk mendapatkan masukan pengambilan keputusan untuk membeli atau menjual harga saham. Selain itu, penelitian ini juga melihat apakah kondisi wabah pandemic covid-19 memiliki pengaruh terhadap pergerakan harga saham tersebut. Kombinasi analisa dari dua indikator tersebut diharapkan dapat memberikan prediksi yang lebih akurat untuk pengambilan keputusan investasi saham. 


\section{Saham}

Saham adalah bukti kepemilikan suatu perusahaan. Dengan kata lain, apabila kita membeli saham suatu perusahaan, kita juga merupakan pemilik dari perusahaan tersebut. Saham dapat didefinisikan sebagai tanda penyertaan modal seseorang atau pihak (badan usaha) dalam suatu perusahaan atau perseroan terbatas (Tandelilin, 2010). Penerbitan saham bertujuan untuk menambah modal suatu perusahaan. Saham juga merupakan instrumen investasi yang banyak digemari investor karena keuntungan yang dihasilkan oleh saham cukup besar. Saham dibedakan menjadi dua, yakni saham biasa dan saham preferen. Pemegang saham preferen memiliki beberapa keistimewaan dibandingkan saham biasa. Salah satu keunggulan saham preferen adalah lebih aman dibandingkan dengan saham biasa, karena pembagian dividen bagi pemegang saham preferen lebih didahulukan. diantaranya:

Pembelian saham suatu perusahaan dapat menghasilkan beberapa keuntungan,

1. Capital gain, merupakan kenaikan harga jual saham terhadap harga beli sebelumnya

2. Dividen, merupakan keuntungan yang diperoleh perusahaan atau bagi hasil atas keuntungan yang dibagikan kepada pemegang saham dari laba yang dihasilkan emiten.

Dibalik semua keuntungan yang telah disebutkan di atas, berbagai risiko yang ditimbulkan saat pembelian saham:

1. Capital loss, merupakan penurunan harga jual dibandingkan harga beli sebelumnya.

2. Likuidasi, merupakan risiko dimana perusahaan itu bangkrut dan tidak bisa bertahan di pasar modal.

\section{Analisis Harga Saham}

Analisis harga dibedakan menjadi analisis fundamental dan analisis teknikal. Analisis fundamental merupakan suatu pendekatan yang dipergunakan investor untuk menilai saham dengan memperhatikan laporan keuangan. Analisis fundamental memperhitungkan berbagai faktor, seperti kondisi ekonomi suatu negara, kebijakan ekonomi, baik makro ataupun mikro (Wira, 2010:3). Analisis fundamental ini dapat dilakukan dengan melakukan analisis top-down. Langkah pertama yang dilakukan adalah melalukan analisis dari makro ekonomi suatu negara agar kita dapat menentukan kapan masuk dan keluar pasar. Analisis makro ini bisa kita lihat dengan memperhatikan kondisi ekonomi suatu negara, politik, tingkat inflasi negara, dan lain-lain. Selanjutnya untuk menentukan pasar mana yang bisa kita masuki, kita bisa melakukan analisis sektoral (industri) dengan melihat perusahaan mana dalam sektor tersebut yang berpeluang untuk tumbuh. Langkah terakhir setelah memilih beberapa perusahaan pada sektor tertentu yang berprospek baik, maka kita harus menganalisis mikro dari masing- masing perusahaan tersebut. Dalam hal ini, kita dapat mengetahui berapa besar harga pasar perusahaan akibat ekonomi makro apakah dalah kondisi mahal (overvalued) atau dalam kondisi murah (undervalued).

Analisis teknikal adalah teknik yang menganalisa fluktuasi harga dalam rentang waktu tertentu atau dalam hubungannya dengan faktor lain misalnya volume transaksi. Karena itu analisis teknikal banyak menggunakan grafik (Wira, 2010:3). Analisis teknikal bertujuan untuk mengetahui kapan waktu yang tepat untuk membeli atau menjual suatu saham perusahaan. Dalam analisis ini, terdapat trendline dalam saham. Trendline merupakan alat ukur yang digunakan trader untuk melakukan analisis teknikal. Penggolongan trendline sendiri dibagi menjadi tiga, yaitu uptrend, downtrend, dan sideways. Uptrend merupakan saham yang lembahnya selalu lebih tinggi dari lembah tahun sebelumya. Downtrend adalah saham yang naik turun namun titik puncaknya selalu lebih rendah dibandingkan titik puncah tahun sebelumnya. Sedangkan sideways merupakan saham yang pergerakannya cenderung mendatar (tidak uptrend atau downtrend). 


\section{Stochastic Oscillator}

Stochastic Oscillator merupakan indikator yang digunakan untuk mengetahui trend. Stochastic Oscillator adalah indikator yang menunjukkan lokasi harga penutupan terakhir dibandingkan dengan range harga terendah tertinggi selama periode waktu tertentu (Wira, 2010). Stochastic Oscillator memiliki dua buah garis, yaitu garis \%K dan garis \%D. Indikator ini banyak digunakan trader karena pengaplikasiannya yang cukup mudah. Terdapat dua prinsip yang perlu diketahui:

Untuk menentukan suatu saham dengan tren naik (bullish) atau tren turun (bearish) dapat dilihat berdasarkan batas-batas oversold (kemungkinan perubahan tren menjadi tren naik) dan overbought (kemungkinan perubahan tren menjadi tren turun) yaitu 20 dan 80 . Angka di bawah 20 dikatakan oversold (kemungkinan akan terjadi perubahan trend menjadi bullish), dan waktu yang tepat untuk membeli saham tersebut. Angka di atas 80 dikatakan overbought (kemungkinan akan terjadi perubahan trend menjadi bearish), dan saat yang tepat untuk menjual saham tersebut.

Sinyal jual dan beli dapat dilihat dari garis \%K dan \%D. Sinyal jual saham dapat lihat apabila garis \%K (garis berwarna merah) memotong \%D (garis berwarna biru) ke bawah. Sedangkan sinyal beli saham ditandakan dengan garis \%K (garis berwarna merah) yang memotong \%D (garis berwarna biru) ke atas.

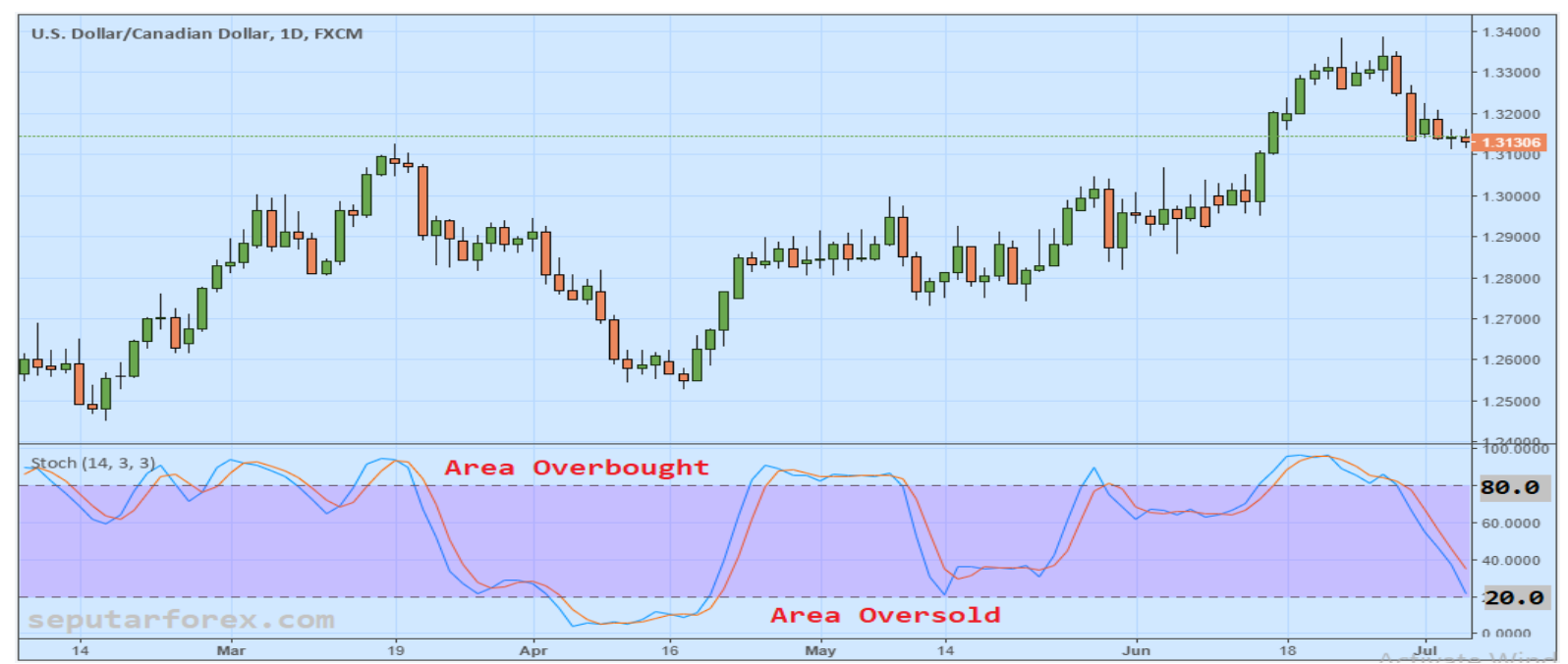

Sumber: https://www.seputarforex.com

\section{Weighted Moving Average (WMA)}

\section{Gambar 1 Sinyal Jual dan Beli}

Berbeda dengan Simple Moving Average yang menggunakan rata-rata dari data terakhir sebagai data perkiraan masa berikutnya yang mana setiap data diberikan bobot yang sama, Weighted Moving Average akan berusaha memprediksi beberapa data terakhir dengan memberikan bobot yang berbeda-beda menggunakan operator OWA (Ordered Weighted Average) (Dwi,Asih, dan Hoyyi, 2019:2). Indikator ini banyak digunakan trader karena memiliki tingkat sensitifitas yang lumayan tinggi. Perbedaan WMA ini dengan SMA adalah perhitungan WMA menggunakan pembobotan. Data dari periode berbeda diberi bobot dan penilaian yang berbeda. 


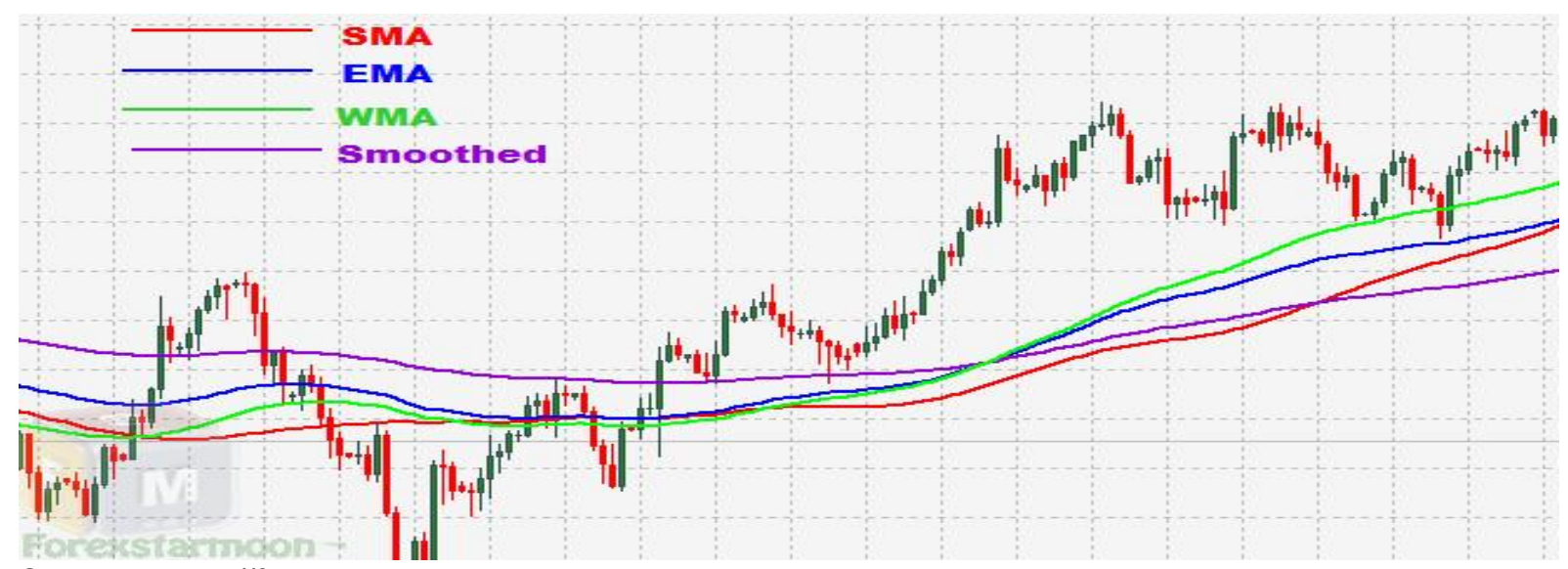

Sumber: https://forexstarmoon.com

\section{Gambar 2 Perbandingan Variasi Moving Average}

Gambar 2 merupakan perbandingan sensitifitas variasi Moving Average indikator yaitu SMA, EMA, WMA, dan Smoothed MA terhadap grafik pergerakan harga saham.Dari gambar tersebut, disimpulkan bahwa Weighted Moving Average (WMA) memiliki sensitifikasi paling tinggi karena pergerakannya yang paling mendekati pergerakan harga saham sesungguhnya. Kemudian disusul oleh EMA, SMA, dan yang terakhir yaitu Smoothed MA yang memiliki tingkat sensitifitas yang paling rendah.

\section{METODE PENELITIAN}

Penelitian ini merupakan penelitian deskriptif. Penelitian deskriptif dilakukan guna mengetahui nilai variabel mandiri yang berlandaskan pada filsafat positivisme, yang digunakan untuk meneliti pada populasi atau sampel tertentu (Sugiyono, 2010). Penelitian ini memaparkan keadaan atau hasil dari penggunaan indikator (WMA) Weighted Moving Average dan Stochastic oscillator sesuai dengan kondisi pasar dan pergerakan harga saham guna mengetahui sinyal jual dan beli. Indikator stochastic oscillator yang dipakai dalam penelitian ini yaitu dengan Length 14 , Smooth K 1, Smooth D 3. Sedangkan pada indikator WMA dipilih 5(garis merah) dan 10 (garis biru), dengan tujuan untuk melihat swing trading dalam jarak dekat. Grafik indikator WMA dan stochastic oscillator diperoleh dari website https://investing.com.

Populasi pada penelitian ini adalah perusahaan pada sektor aneka industri yang terdaftar di Bursa Efek Indonesia. Pemilihan sampel dilakukan dengan metode purposive sampling berdasarkan beberapa kriteria. Metode digunakan apabila mempunyai pertimbanganpertimbangan tertentu di dalam pengambilan sampelnya atau penentuan sampel untuk tujuan tertentu (Gunawan, 2013). Kriteria pemilihan sampel adalah sebagai berikut: (1) perusahaanperusahaan go public yang termasuk dalam sektor aneka industri di Bursa Efek Indonesia periode 2015-2020 (2) Perusahaan yang aktivitas sahamnya tidak berhenti selama periode pengamatan. Berdasarkan kriteria tersebut terdapat 5 perusahaan terpilih yaitu (1) PT. KMI Wire and Cable Tbk. dengan kode saham KBLI (2) PT. Supreme Cable Manufacturing Corporation Tbk dengan kode saham SCCO (3) PT. Indorama Syntetics Tbk dengan kode saham INDR (4) PT Indospring Tbk dengan kode saham INDS dan (5) PT. Kabelindo Murni Tbk dengan kode saham KBLM. Data, informasi dan grafik pergerakan harga saham yang digunakan dalam penulisan artikel diperoleh dari website www.idx.co.id, https://forexstarmoon.com,https://seputarforex.com, dan https://investing.com. 


\section{HASIL DAN PEMBAHASAN}

Hasil dan pembahasan berisi hasil analisis dari grafik pergerakan harga saham dengan menunjukkan sinyal beli dan jual dari kelima perusahaan terpilih selama periode 2015-2020 dengan menggunakan indikator Stochastic Oscillator dan WMA (Weighted Moving Average).

\section{Indikator Stochastic Oscillator}

Indikator Stochastic yang digunakan dalam artikel ini yaitu dengan Length 14 , Smooth $\mathrm{K} 1$, Smooth D 3.

\section{A. SCCO saham PT. Supreme Cable Manufacturing Corporation Tbk}

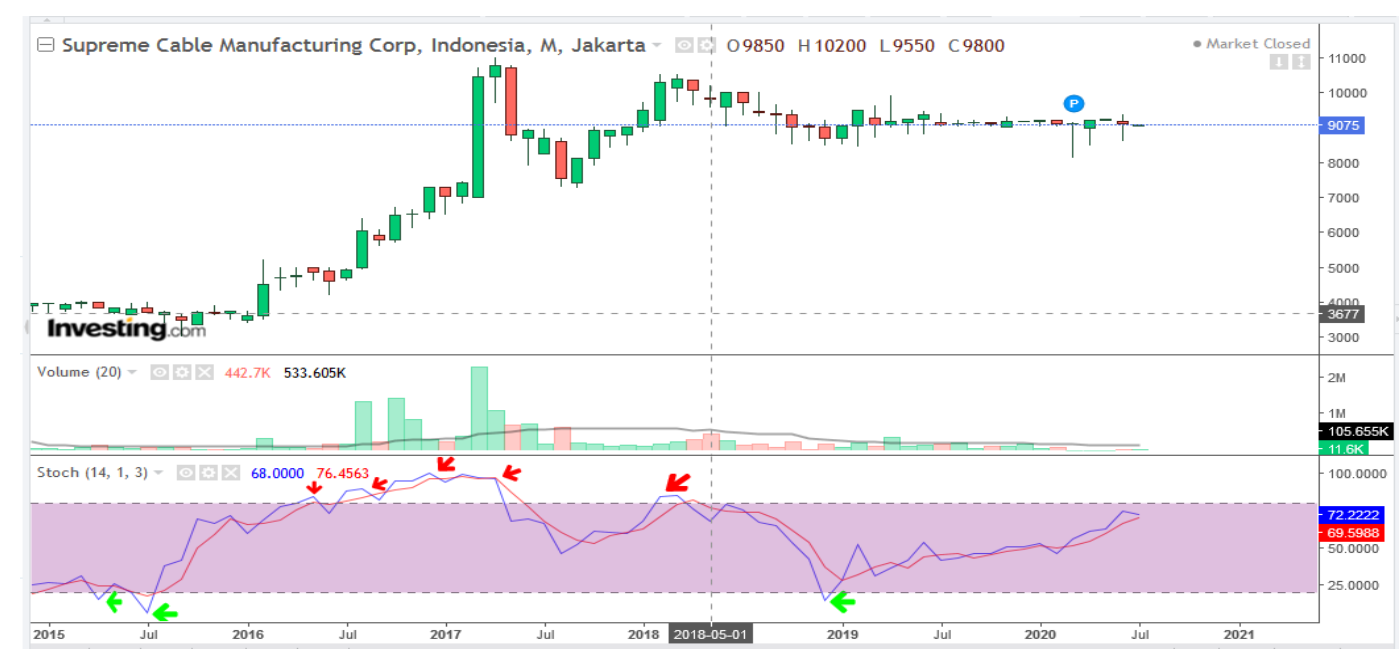

Sumber : http://investing.com

\section{Gambar 3 Grafik Saham SCCO Indikator Stochastic}

Berdasarkan grafik harga saham pada gambar 3, garis panah merah(menunjukkan overbought) dan panah hijau (menunjukkan oversold). Pada bulan April 2015 dan Juli 2015, kondisi yang terjadi saat itu adalah sedang mengalami kondisi oversold atau jenuh jual. Kondisi oversold ini dapat terlihat ketika garis grafik \%K dan atau \%D memotong garis dibawah nilai 20 . Oversold, merupakan kondisi dimana harga sudah terlalu rendah dan akan segera balik arah menjadi naik, sehingga disarankan pada kondisi ini adalah waktu yang tepat untuk membeli saham. Setelah mencapai kondisi oversold garis akan naik kembali berfluktuasi sesuai harga saham, dapat mengalami kondisi overbought dan dapat kembali ke kondisi oversold seperti yang terjadi pada bulan Desember 2018, terlihat garis \%K memotong dibawah garis nilai 20. Sedangkan kondisi overbought terjadi ketika garis $\% \mathrm{~K}$ dan atau \%D memotong garis diatas nilai 80 . Terlihat pada grafik di atas kondisi overbought terjadi pada bulan Mei 2016 dimana garis \%K dan \%D memotong garis ke atas nilai 80 dan kondisi ini kembali muncul pada bulan Oktober 2016 hingga April 2017. Kondisi overbought merupakan kondisi dimana sudah terlalu banyak trader yang membuka dan menahan posisi beli, di lain sisi sudah tidak ada lagi yang membeli lagi. Sehingga kondisi ini merupakan waktu yang tepat untuk menjual saham yang dimiliki.

Selain untuk mengetahui kondisi oversold dan overbought, indikator stochastic dapat digunakan untuk mengetahui sinyal beli dan jual. Sinyal beli muncul ketika \% K memotong \%D dari bawah ke atas dan inilah waktu yang tepat untuk membeli saham SCCO, seperti yang terlihat pada bulan Juli 2015 (perhatikan grafik yang diberi lingkaran hitam). Sedangkan sinyal jual muncul ketika \%K memotong \%D dari atas ke bawah seperti yang terjadi pada bulan Juli 2018(perhatikan grafik yang diberi lingkaran hitam). 
Pada saat tahun 2020, adanya pandemik menyebabkan perdagangan saham menjadi sangat berfluktuasi hingga tidak terduga. Namun, pada saham SCCO terlihat pada grafik bahwa tidak terjadi pergerakan yang sangat fluktuatif tetapi garis akan semakin mendekati kondisi overbought dan langkah yang tepat sebelum terjadi overbought adalah kita dapat menjual saham SCCO.

\section{B. INDR}

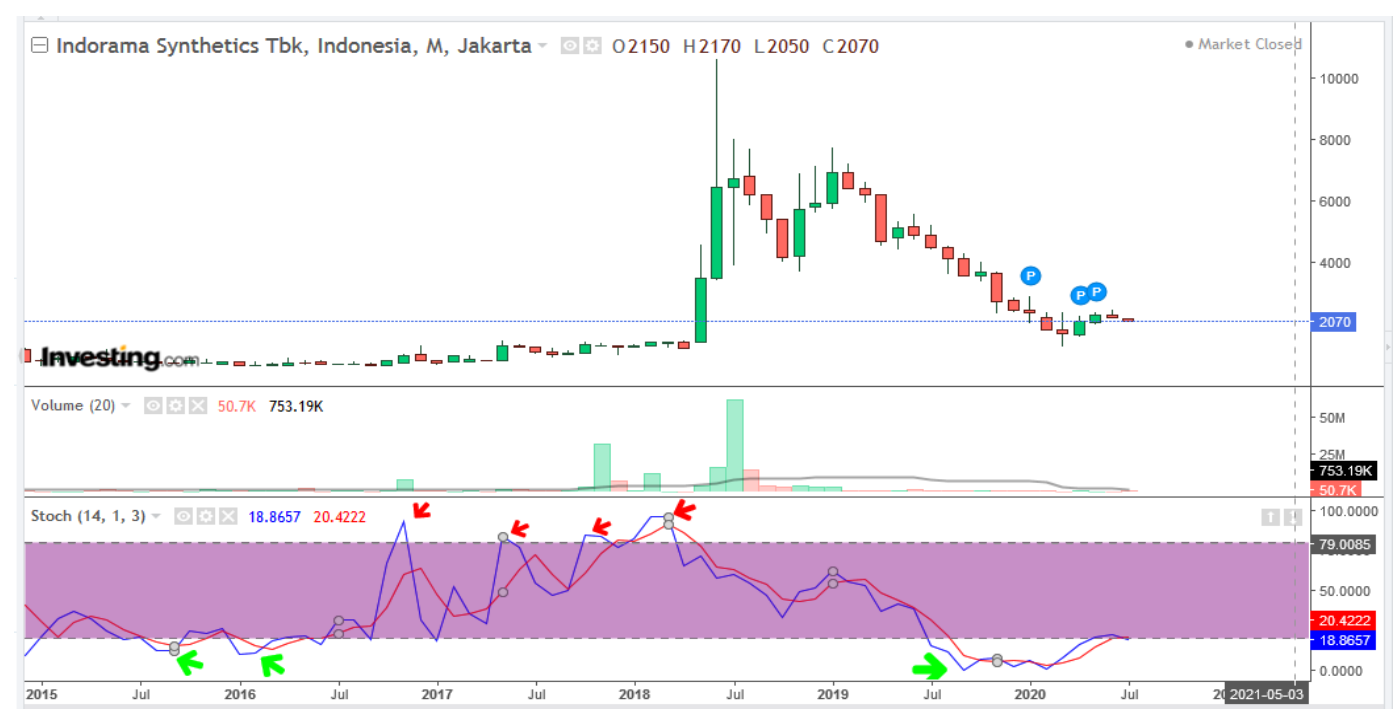

Sumber : http://investing.com

\section{Gambar 4 Grafik Saham INDR Indikator Stochastic}

Dalam analisa saham INDR, panah berwarna hijau menunjukan kondisi oversold dan panah berwarna merah akan menunjukkan kondisi overbought. Telihat pada grafik harga saham pada gambar 4 terlihat saham INDR selama periode 2015 - 2020 sangat berfluktuatif. Kondisi oversold terjadi pada bulan Agustus 2015 dan pada awal tahun 2016 yaitu dibulan Januari hingga April. Kembali normal pada bulan Mei dan kembali oversold pada bulan Juni 2016 dan langsung berbalik arah melewati garis 20. Setelah mengalami kondisi oversold, saham INDR juga sempat mengalami kondisi overbought pada November 2011. Terlihat garis \%K memotong ke atas garis 80 dan langsung terpantulkan hingga kembali ke kondisi normal. Kondisi overbought juga terjadi beberapa kali pada tahun 2017 hingga tahun 2018 (dapat diperhatikan anak panah berwarna merah). Kemudian terjadi kembali kondisi oversold pada bulan Juli 2019 dan bertahan hingga bulan Juni 2020. Bertahannya kondisi ini didukung pula dengan munculnya pandemic Covid-19 yang mengakibatkan jual beli saham ikut terdampak. Keputusan yang harus diambil pada saat kondisi overbought adalah menjual saham, karena pada kondisi overbought terlalu banyak trader yang membuka dan menahan posisi beli, di lain sisi sudah tidak ada lagi yang membeli lagi, sehingga harga akan mencapai puncak sebelum berbalik ke arah turun kembali. Sedangkan ketika muncul kondisi oversold keputusan yang dapat diambil adalah membeli saham tersebut karena kondisi ini muncul dimana harga sudah terlalu rendah dan akan segera balik arah menjadi naik. 


\section{INDS}

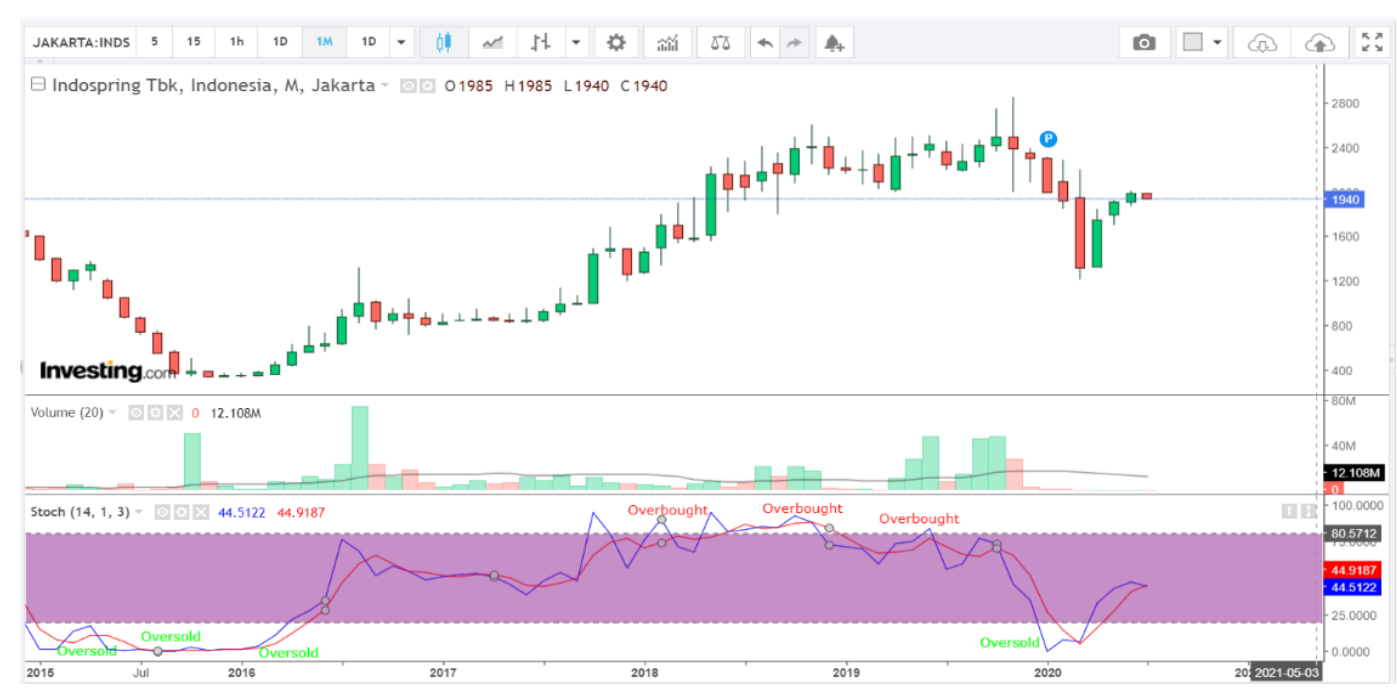

Sumber : http://investing.com

Gambar 5 Grafik Saham INDS Indikator Stochastic

Pada analisa pergerakan harga saham INDS, terlihat bahwa selama periode 2015 - 2020 kondisi jual beli saham INDS sering mengalami kondisi jenuh jual maupun beli. Terlihat pada grafik di awal tahun 2015, dimana saat itu sudah terjadi kondisi jenuh jual yang ditandai dengan adanya garis $\% \mathrm{~K}$ dan atau \%D yang memotong ke bawah garis nilai 20 , dan kondisi ini bertahan sangat lama bahkan lebih dari satu tahun dimana garis menunjukkan kembali pada posisi 20-80 baru terjadi pada bulan Juni 2016. Sama seperti yang telah dijelaskan pada analisa perusahaan sebelumnya, pada saat terjadi kondisi oversold merupakan waktu yang tepat untuk membeli saham. Pada saham INDS ini juga mengalami kondisi overbought yaitu pada bulan Oktober 2017 dan terus berfluktuasi dikondisi ini hingga bulan Juni 2019. Pada saat kondisi inilah merupakan waktu yang tepat untuk menjual saham yang kita miliki sebelum terjadi balik arah. Dan kondisi oversold kembali muncul pada awal tahun 2020 hingga Maret 2020. Dan pada bula April 2020, kondisi tidak lagi oversold sedangkan di Indonesia sedang ramai dengan adanya wabah pandemi Covid-19, ini mendandakan bahwa munculnya pandemic tidak begitu berpengaruh pada kegiatan jual beli saham INDS.

D. KBLI

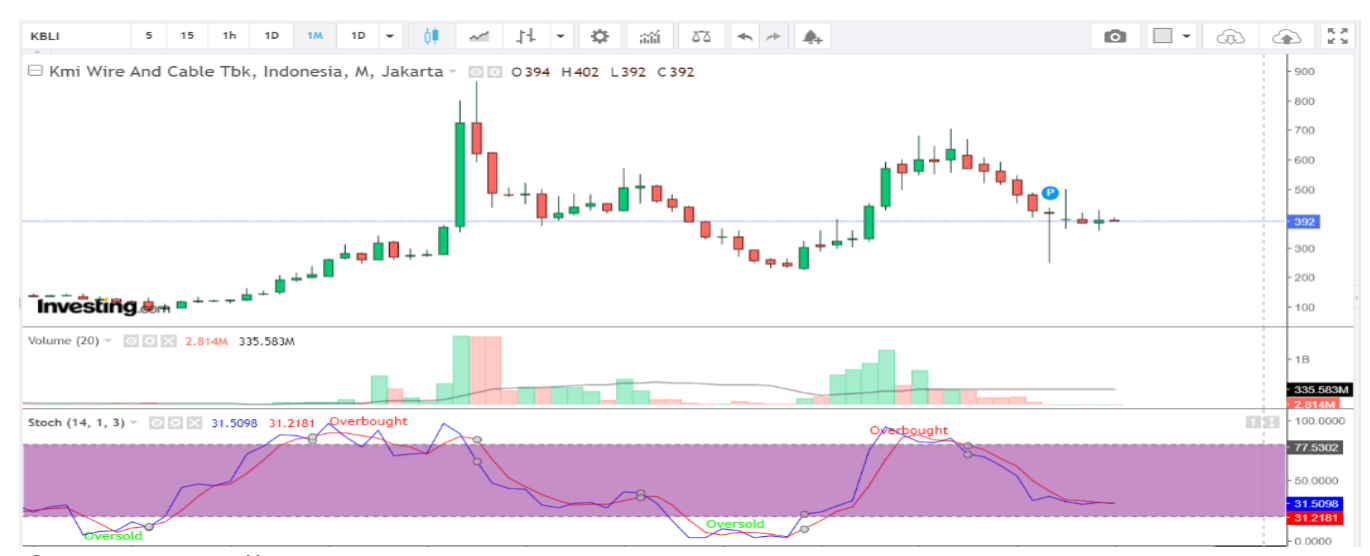

Sumber : http://investing.com

Gambar 6 Grafik Saham KBLI Indikator Stochastic 
Kondisi yang terjadi pada perusahaan KBLI tidak jauh berbeda dengan perusahaan sebelumnya dimana kondisi oversold dan overbought beberapa kali terjadi dengan kurun waktu yang cukup lama. Terlihat pada gambar 6, kondisi oversold terjadi pada bulan April 2015 hingga bulan September 2015. Kemudian kondisi ini kembali terjadi pada bulan Mei 2018 hingga akhir tahun 2018. Pada kondisi oversold inilah, kita dapat membeli saham, karena selain pada kondisi jenuh jual terdapat sinyal beli pada saat \%K memotong \%D dari bawah. Kemudian untuk kondisi overbought terjadi pada bulan April 2016 hingga Oktober 2016 dan kembali terjadi pada bulan Februari hingga April 2017. Setelah itu sempat mengalami kondisi oversold dan kembali terjadi kondisi overbought pada bulan Mei hingga September 2019. Kondisi overbought ini merupakan peluang untuk menjual saham yang dimiliki karena pada saa itu terjadi kondisi jenuh beli dimana banyak para trader membeli saham dan akhirnya tertahan pada posisi beli, didukung dengan adanya perpotongan gari \% $\mathrm{K}$ yang memotong $\% \mathrm{D}$ dari atas.

Kondisi yang terjadi pada tahun 2020 khususnya pada tahun 2020, dari awal tahun berjalan higga saat ini menunjukkan adanya pergerakan harga saham yang semakin menurun hingga kondisi yang terjadi akan mengarah ke terjadinya kondisi oversold. Pada tahun 2020, khususnya dimulai pada bulan April dimana pandemi Covid-19 sedang merebak di Indonesia, banyak sektor usaha terkena dampak termasuk dalam kegiatan jual beli saham. Dilihat pada grafik di atas, dapat terlihat pada awal Januari menuju ke bulan April banyak yang menjual saham KBLI yang terlihat pada garis yang menurun menuju nilai 20 , penurunan ini berhenti pada bulan April dan setelahnya mengalami stagnasi hingga bulan Juni. Hal ini berarti pandemi Covid-19 tidak terlalu mempengaruhi saham KBLI secara signifikan.

\section{E. KBLM}

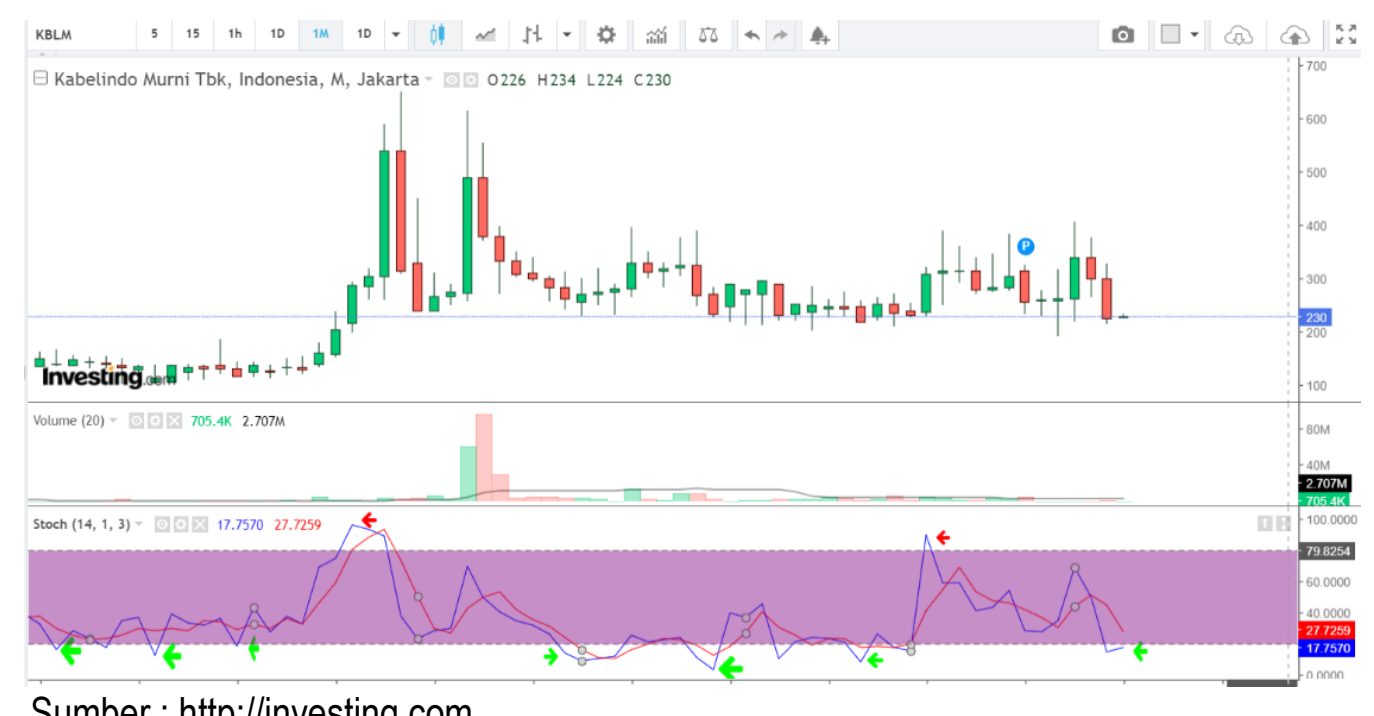

Sumber : http://investing.com

\section{Gambar 7 Grafik Saham KBLM Indikator Stochastic}

Pada analisis perubahan harga saham KBLM masih relatif sama dengan indikator yang digunakan pada analisis perusahaan yang sebelumnya. Pada perusahaan ini kondisi yang terjadi adalah terjadinya jenuh jual yang dapat diperhatikan pada grafik yang diberikan panah berwarna hijau. Kondisi ini terjadi dimulai pada bulan Februari 2015 dan langsung terjadi balik arah. Begitu pula dengan kondisi oversold selanjutnya yang terjadi pada bulan Mei, Agustus 2015 dan awal tahun 2016, dimana terjadi kondisi oversold dan langsung terjadi balik arah menuju kondisi normal. Setelah itu harga saham masih terus berfluktuatif sampai kondisi overbought dan kondisi oversold 
kembali terjadi pada bulan September 2017 hingga bulan Juni 2019, walaupun sempat beberapa kali mengalami balik arah kondisi yang terjadi masih didominasi oleh kondisi oversold.

Pada perusahaan KBLM , kondisi overbought terjadi pada bulan Agustus hingga Oktober 2016. Dimana terlihat garis $\% \mathrm{~K}$ dan atau \%D memotong ke atas garis 80 dan kondisi ini tepat untuk menjual saham kita. Pada kondisi jenuh beli ini juga muncul sinyal jual yaitu ketika \%K memotong $\% \mathrm{D}$ dari atas dapat terlihat pada bulan Oktober 2016. Kemudiain kondisi jenuh beli kembali terjadi pada bulan Juli 2019 namun pada saat itu langsung terjadi balik arah. Pada saat kondisi seperti inilah merupakan peluang untuk menjual saham sebelum garis mengalami balik arah dan harga akan menjadi turun.

Pada tahun 2020 khususnya pada saat pandemi Covid-19, saham perusahaan KBLM cukup terpengaruh terutama terhitung dari maraknya kasus pandemi di Indonesia yaitu pada bulan April. Terlihat pada grafik, garis menujukkan arah menuju ke kondisi oversold dan akhirnya terjadi pada bulan Juni. Hal ini terjadi karena banyaknya trader maupun investor yang menjual sahamnya pada saat kondisi pandemi ini.

\section{Weighted Moving Average (WMA)}

Selain menganalisa perubahan harga saham dengan stochastic oscillator, penelitian ini juga melhat pergerakan harga saham dengan menggunakan indikator WMA. Indikator WMA yang dipilih yaitu WMA 5 (garis merah) dan 10 (garis biru), dengan tujuan untuk melihat swing trading dalam jarak dekat.

\section{A. SCCO}

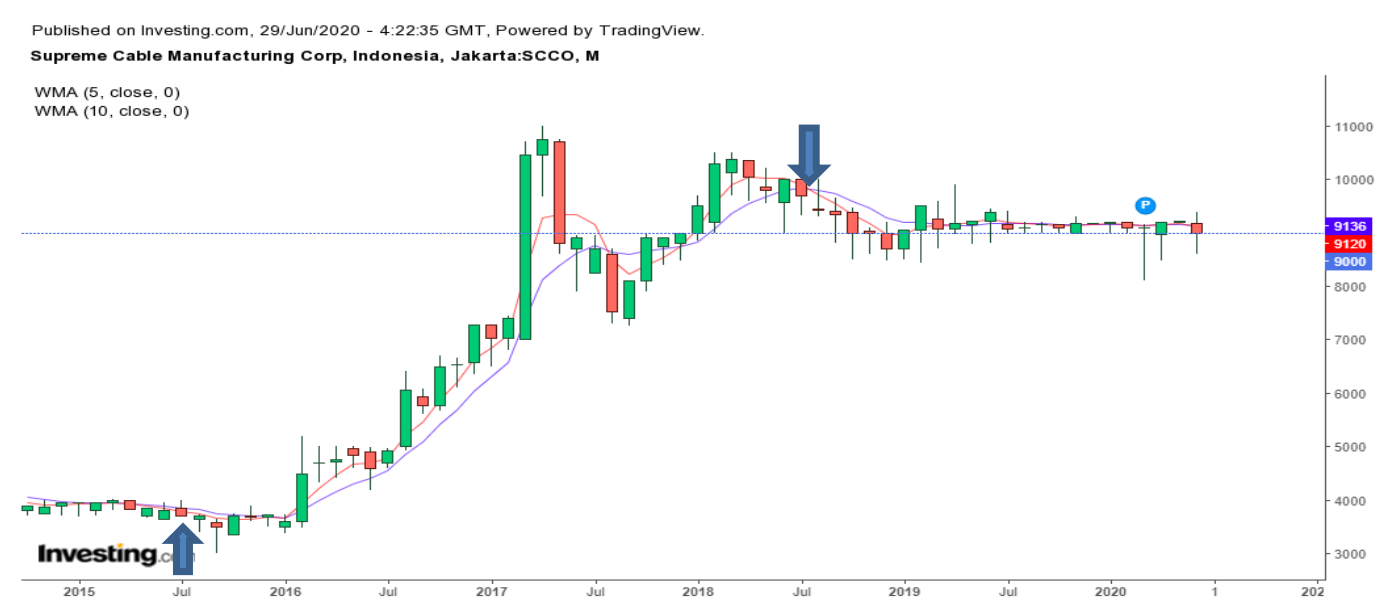

Sumber : http://investing.com

\section{Gambar 8 Grafik Saham SCCO Indikator WMA}

Berdasarkan grafik harga saham pada gambar 8 , dapat dilihat bahwa panah atas dari bulan Juli tahun 2015 yang menunjukkan bahwa MA 5 memotong MA 10 dari sisi bawah ke atas, maka itu merupakan sinyal beli karena terjadi crossing atau disebut juga dengan golden cross, dan setelah itu keadaan trend menjadi naik sampai bulan juli tahun 2018. Kemudian, perhatikan pada gambar panah bawah setalah tren naik sampai bulan juli 2018 yang menunjukkan bahwa MA 5 memotong MA 10 dari sisi atas ke bawah, maka itu merupakan sinyal jual terjadi crossing kembali atau yang sering disebut death cross, dan setelah itu trend turun sampai dengan awal 2019.

Kita bisa perhatikan bahwa dari tahun 2015 awal sampai bulan Juni 2020, keadaan trend saham SCCO adalah uptrend sehingga investor dapat membeli saham SCCO pada awal 2015. Kemudian perhatikan candle stick pada tahun 2020 keadaan trend saham SCCO berada pada 
posisi sideways. Hal ini dapat menjadi gambaran bahwa adanya pandemic covid-19 tidak berpengaruh secara signifikan terhadap perusahaan tersebut.

\section{B. INDR}

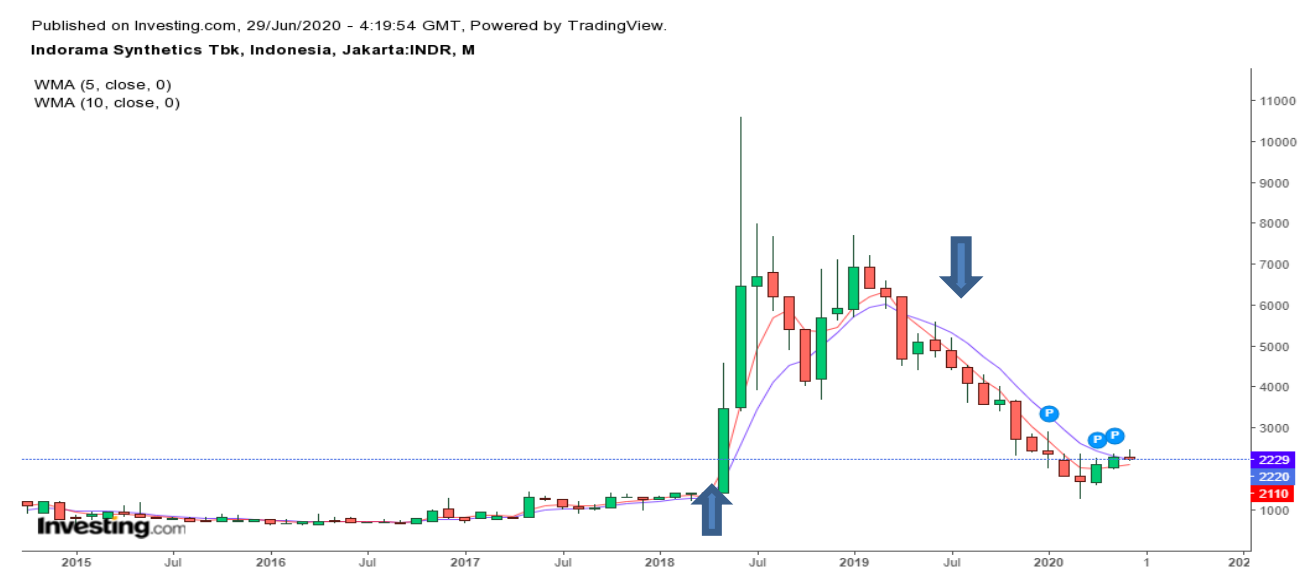

Sumber : http://investing.com

\section{Gambar 9 Grafik Saham INDR Indikator WMA}

Pada analisa perusahaan INDR, perhatikan pada gambar panah atas pada grafik di atas, terlihat dari awal tahun 2018 bulan April, menunjukkan bahwa MA 5 memotong MA 10 dari sisi bawah ke atas, ini merupakan sinyal beli karena terjadi crossing, dan setelah itu keadaan trend menjadi naik sampai bulan maret tahun 2019. Kemudian perhatikan pada gambar panah bawah setalah tren naik sampai bulan Maret 2019, ini menunjukkan bahwa MA 5 memotong MA 10 dari sisi atas ke bawah, maka itu merupakan sinyal jual terjadi crossing kembali, setelah itu keadaan trend menjadi turun sampai bulan Maret 2020. Kemudian dalam keadaan terakhir ada kemungkinan bahwa MA 5 dan MA 10 akan bertemu kembali lagi.

Dapat diperhatikan bahwa dari tahun 2015 awal sampai 2020 bulan juni keadaan trend saham INDR adalah SIDEWAYS, sehingga dapat membeli pada awal 2018 apabila kita sebagai investor dapat menjual pada tahun 2019. Kemudian kita perhatikan candle stick pada tahun 2020, keadaan trend saham INDR adalah UPTREND semenjak adanya pandemi corona sampai bulan Juni, menunjukkan kondisi pandemi tidak berpengaruh secara signifikan terhadap perusahaan tersebut.

\section{IDNS}

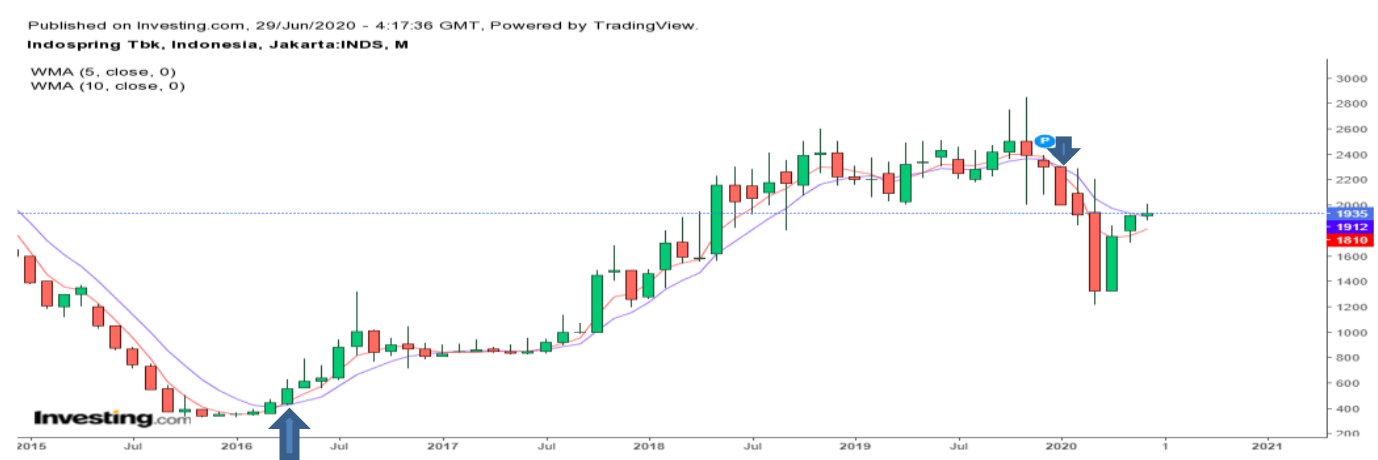

Sumber : http://investing.com

Gambar 10 Grafik Saham INDS Indikator WMA 
Berdasarkan grafik saham INDS di atas, gambar panah atas pada bulan Maret 2016 menunjukkan bahwa MA 5 memotong MA 10 dari sisi bawah ke atas, maka itu merupakan sinyal beli karena terjadi crossing, dan setelah itu keadaan trend menjadi naik jauh dapat terl ihat sampai tahun 2020 awal. Kemudian, perhatikan pada gambar panah bawah setalah trend naik sampai awal tahun 2020, menunjukkan bahwa MA 5 memotong MA 10 dari sisi atas ke bawah, maka itu merupakan sinyal jual terjadi crossing kembali, setelah itu keadaan trend menjadi turun sampai awal 2020 bulan April. Kemudian dalam keadaan terakhir ada kemungkinan bahwa MA 5 dan MA 10 akan bertemu kembali.

Dapat diperhatikan bahwa dari tahun 2015 awal sampai bulan Juni 2020, keadaan trend saham INDS adalah SIDEWAYS, sehingga kita baru dapat membeli pada awal 2016 dan bisa menjual pada tahun 2020 karena trend tersebut naik secara tajam dari 2016 sampai 2020. Sedangkan pada awal tahun 2015 sampai awal tahun 2016 trend tersebut sedang turun. Kemudian perhatikan candle stick pada tahun 2020, terlihat dimana keadaan trend saham INDS adalah UPTREND semenjak adanya pandemic corona sampai bulan Juni. Ini menandakan bahwa adanya pandemi, tidak mempengaruhi secara signifikan terhadap perusahaan tersebut akan tetapi pada awal tahun 2020 sempat terjadi downtrend sebelum adanya corona.

D. KBLI

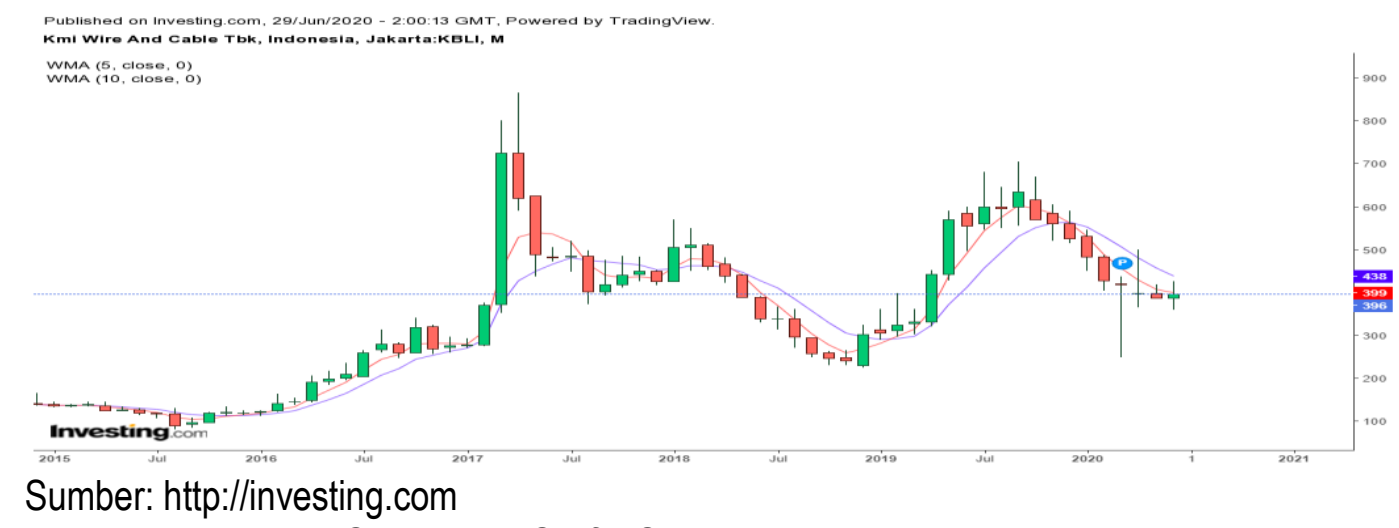

Gambar 11 Grafik Saham KBLI Indikator WMA

Kemudian kita lihat pada perusahaan KBLI dengan indikator yang digunakan masih sama seperti pada perusahaan sebelumnya. Berdasarkan grafik di atas perhatikan pada gambar panah atas dari Bulan Juli 2015 yang menunjukkan bahwa MA 5 memotong MA 10 dari sisi bawah ke atas, maka itu merupakan sinyal beli karena terjadi crossing, dan setelah itu keadaan trend menjadi naik yang dapat kita lihat sampai bulan Oktober 2019. Kemudian, kita perhatikan pada gambar panah bawah setalah trend naik sampai bulan November 2019 yang menunjukkan bahwa MA 5 memotong MA 10 dari sisi atas ke bawah, maka itu merupakan sinyal jual terjadi crossing kembali, setelah itu keadaan trend menjadi turun sampai bulan Juni 2020. Kemudian dalam keadaan terakhir ada kemungkinan bahwa MA 5 dan MA 10 akan bertemu kembali.

Kita dapat perhatikan bahwa dari awal tahun 2015 sampai 2020 bulan Juni keadaan trend saham KBLI adalah UPTREND, sehingga kita dapat membeli pada awal 2016 dan bisa menjual pada tahun 2019 pada bulan Oktober. Kemudia kita perhatikan candle stick pada tahun 2020 keadaan trend saham INDR adalah DOWNTREND semenjak awal tahun. Kemudian dengan adanya pandemi Covid-19 sampai bulan Juni mempengaruhi secara signifikan terhadap perusahaan tersebut yang membuat trend masih menurun. 


\section{E. KBLM}

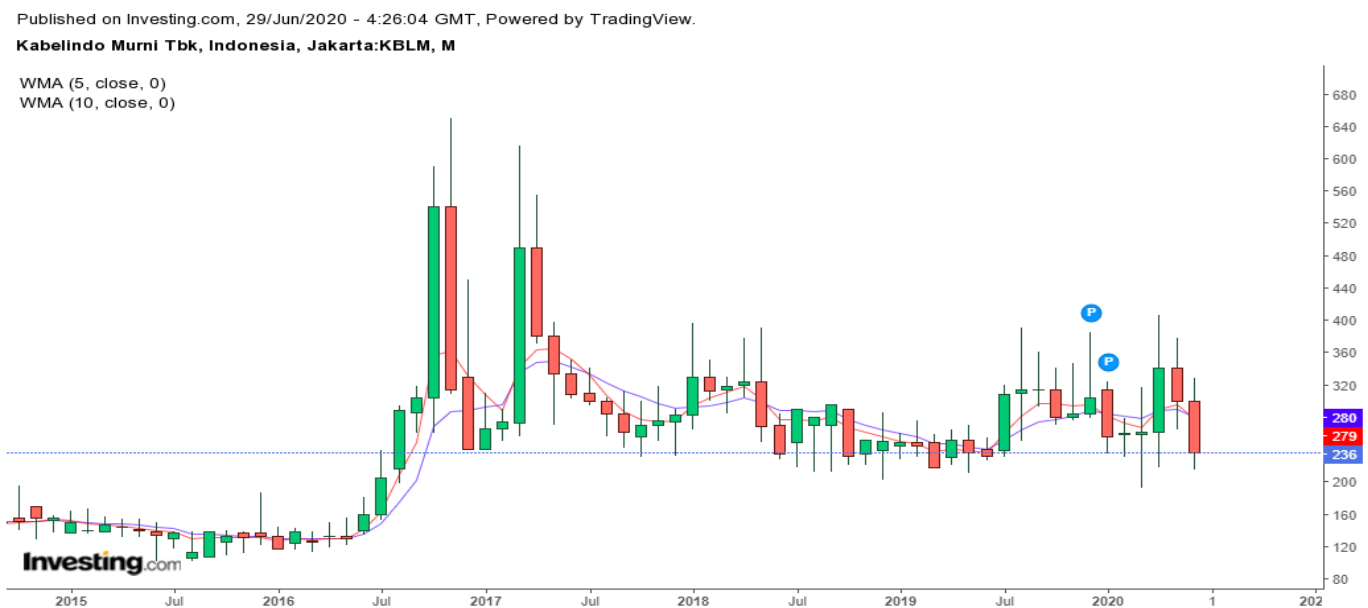

Sumber : http://investing.com

\section{Gambar 12 Grafik Saham KBLM Indikator WMA}

Berdasarkan grafik saham KBLM, dapat diperhatikan pada gambar panah bawah yang menunjukkan pada awal tahun 2016 MA 5 memotong MA 10 dari sisi bawah ke atas, maka itu merupakan sinyal beli karena terjadi crossing, dan setelah itu keadaan trend menjadi naik yang dapat terlihat sampai tahun 2018 bulan April. Kemudian, perhatikan pada gambar panah bawah setelah trend naik sampai bulan Maret 2018, itu menunjukkan bahwa MA 5 memotong MA 10 dari sisi atas ke bawah, maka itu merupakan sinyal jual terjadi crossing kembali, setelah itu keadaan trend menjadi turun sampai tahun 2019 bulan Juli. Kemudian pada kondisi terakhir terakhir ada kemungkinan bahwa MA 5 dan MA 10 akan bertemu kembali.

Kita dapat perhatikan bahwa dari awal tahun 2015 sampai 2020 bulan Juni, keadaan trend saham KBLM cenderung SIDEWAYS, sehingga kita baru dapat membeli pada bulan Juni 2016 dan bisa menjual pada tahun 2018 bulan April. Kemudian kita perhatikan candle stick pada awal tahun 2020 keadaan trend saham KBLM adalah SIDEWAYS. Kemudian dengan adanya pandemi Covid19 sampai bulan Juni tidak berpengaruh secara signifikan terhadap perusahaan tersebut.

\section{WMA STOCHASTIC}

\section{A. SCCO}

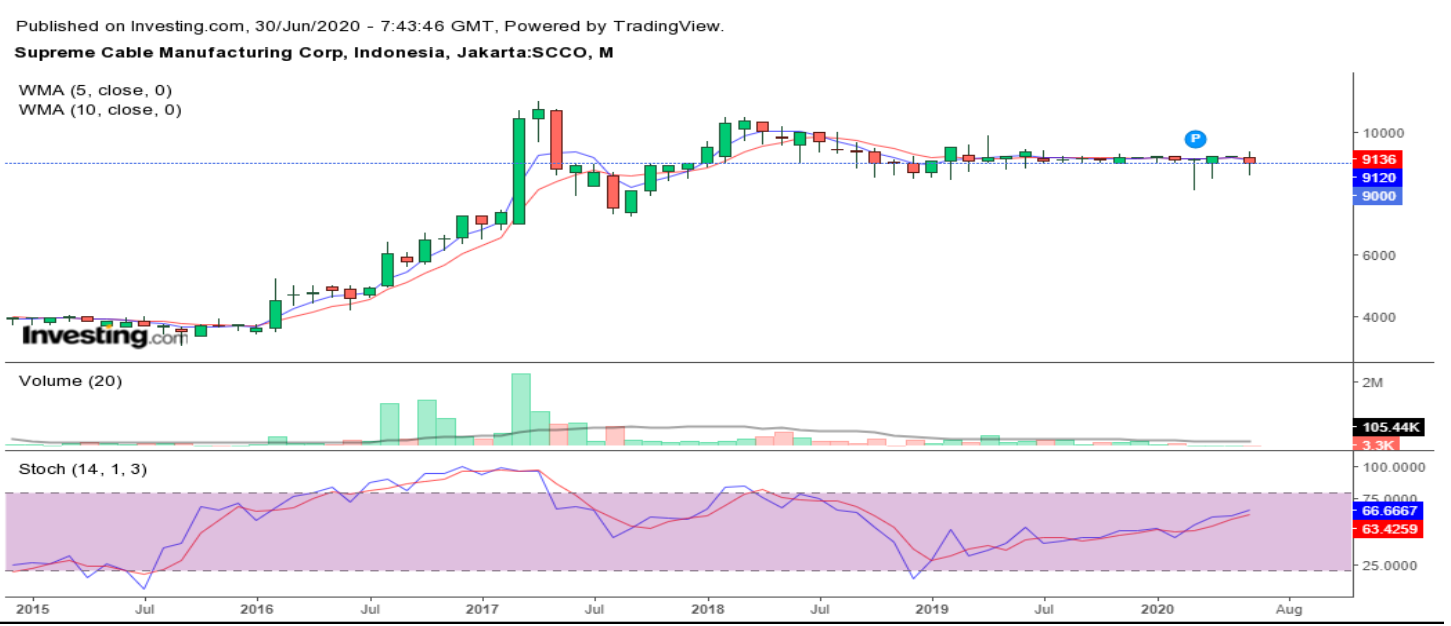

Sumber : http://investing.com

Gambar 13 Grafik Saham SCCO Indikator WMA dan Stochastic 
Pada pembahasan kali ini, kami akan membahas mengenai hubungan antara indikator WMA dan Stochastic dengan menggunakan ukuran yang sama baik pada WMA maupun stochastic. Berdasarkan grafik di atas perhatikan pada candle stick bulan Juli 2015 yang menunjukkan bahwa MA 5 memotong MA 10 dari sisi bawah ke atas, maka itu merupakan sinyal beli karena terjadi crossing, dan setelah itu keadaan trend menjadi naik yang dapat terlihat sampai bulan Juli tahun 2018 terkonfirmasi dengan stochastic pada bulan Juli 2015 terdapat sinyal beli karena garis \% K memotong ke atas garis \%D yang berarti itu sedang dalam keadaan oversold. Kemudian, perhatikan pada candle stick setelah trend naik sampai bulan Juli 2018 menunjukkan bahwa MA 5 memotong MA 10 dari sisi atas ke bawah, maka itu merupakan sinyal jual terjadi crossing kembali, setelah itu keadaan trend menjadi turun sampai awal 2019 terkonfirmasi dengan stochastic pada bulan Juli 2018 terdapat sinyal jual karena garis \%K memotong ke bawah garis \%D yang berarti itu sedang dalam keadaan overbought atau jenuh beli. Berdasarkan keterangan di atas menunjukkan bahwa kita dapat membeli saham SCCO pada bulan Juli 2015 dan jual pada bulan Juli 2018.

\section{B. INDR}

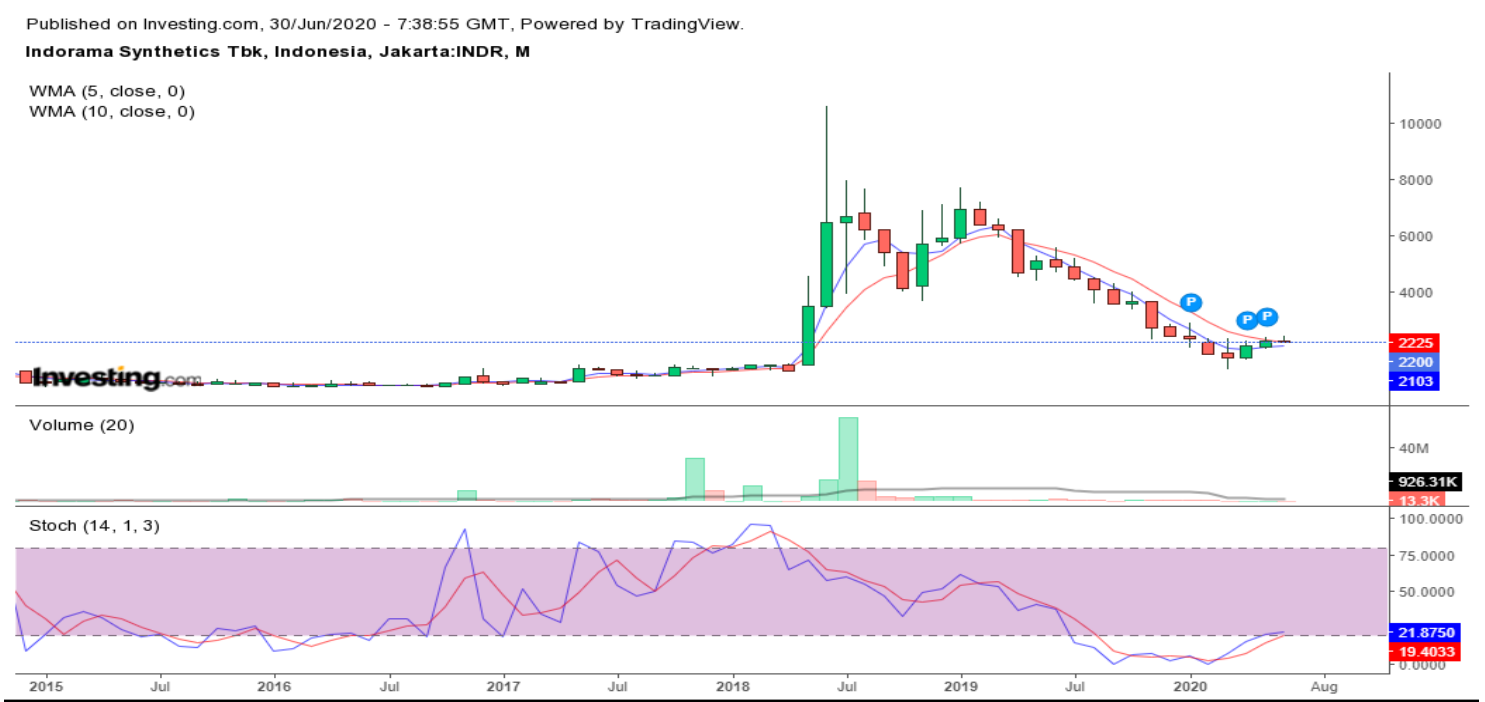

Sumber : http://investing.com

\section{Gambar 14 Grafik Saham INDR Indikator WMA dan Stochastic}

Berdasarkan grafik di atas perhatikan pada candlestick dari bulan Juni 2016 yang menunjukkan bahwa MA 5 memotong MA 10 dari sisi bawah ke atas, maka itu merupakan sinyal beli karena terjadi crossing yang terkonfirmasi dengan stochastic pada bulan Juni 2016 terdapat sinyal beli karena garis \% $\mathrm{K}$ memotong ke atas garis \%D yang berarti itu sedang dalam keadaan oversold atau jenuh beli. Kemudian, kita perhatikan pada candle stick setelah trend naik sampai bulan Maret 2019 yang menunjukkan bahwa MA 5 memotong MA 10 dari sisi atas ke bawah, maka itu merupakan sinyal jual terjadi crossing kembali, akan tetapi terkonfirmasi dengan stochastic pada bulan Maret 2018 terlebih dahulu terdapat sinyal cepat dibanding indikator WMA yaitu sinyal jual karena garis \% $\mathrm{K}$ memotong ke bawah garis \%D yang berarti itu sedang dalam keadaan overbought atau jenuh beli. Berdasarkan keterangan di atas menunjukkan bahwa kita dapat membeli saham INDR pada bulan Juni 2016 dan jual pada bulan Maret 2018. 


\section{INDS}

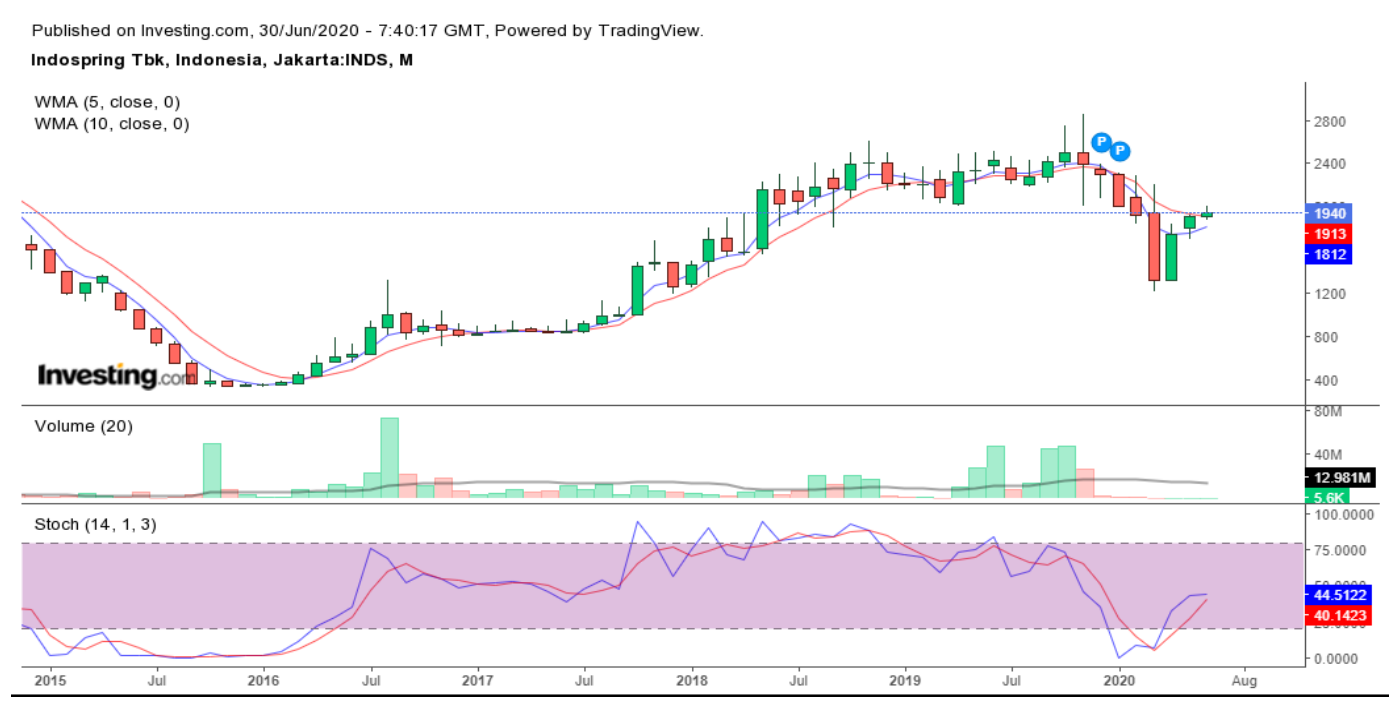

Sumber : http://investing.com

\section{Gambar 15 Grafik Saham INDS Indikator WMA dan Stochastic}

Berdasarkan grafik di atas perhatikan pada candle stick dari awal tahun 2016 bulan Maret yang menunjukkan bahwa MA 5 memotong MA 10 dari sisi bawah ke atas, maka itu merupakan sinyal beli karena terjadi crossing, dan setelah itu keadaan trend menjadi naik jauh, yang dapat terlihat sampai tahun 2020 awal terkonfirmasi dengan stochastic pada tahun 2016 awal terdapat sinyal beli karena garis \% $\mathrm{K}$ memotong ke atas garis \% $\mathrm{D}$ yang berarti itu sedang dalam keadaan oversold atau jenuh jual. Kemudian, kita perhatikan pada candle stick setelah trend naik sampai bulan Juli 2018, menunjukkan bahwa MA 5 memotong MA 10 dari sisi atas ke bawah, maka itu merupakan sinyal jual terjadi crossing kembali, setelah itu keadaan trend menjadi turun sampai awal 2020 terkonfirmasi dengan stochastic pada bulan Oktober tahun 2018 terdapat sinyal jual karena garis \% $\mathrm{K}$ memotong ke bawah garis \%D yang berarti itu sedang dalam keadaan overbought atau jenuh beli. Berdasarkan keterangan menunjukkan bahwa kita dapat membeli saham INDS pada awal tahun 2016 dan menjual pada bulan Oktober 2018.

\section{KBLI}

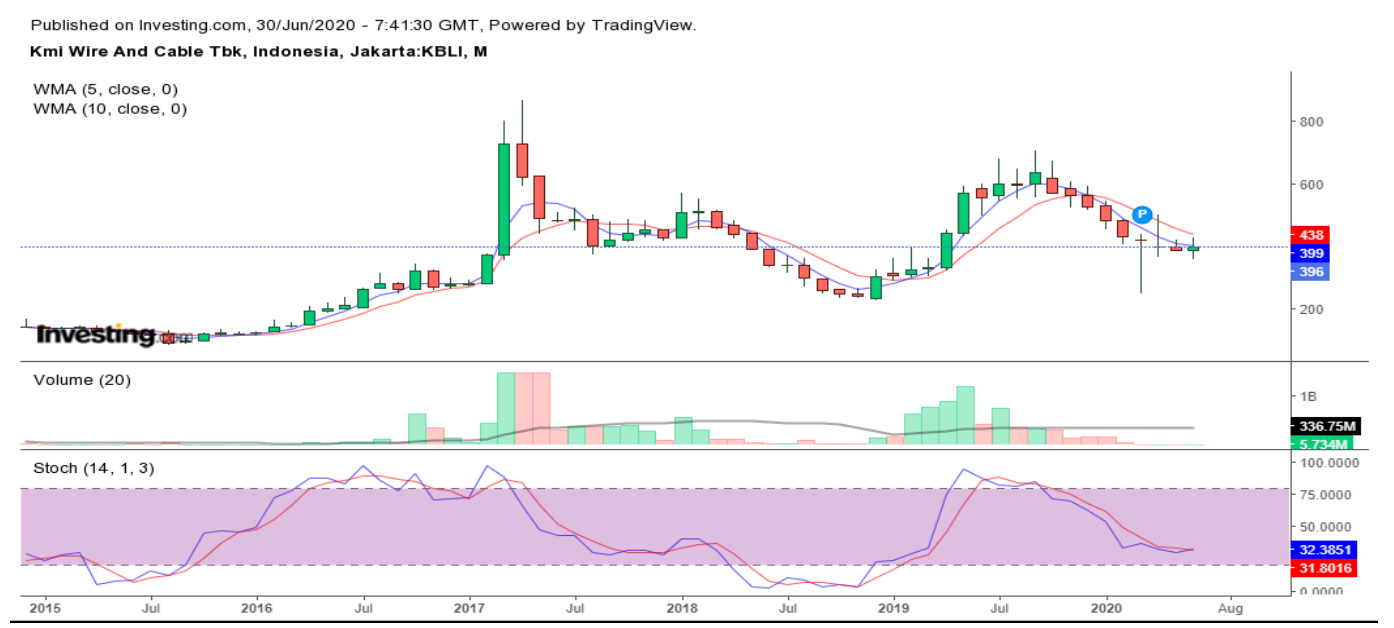

Sumber : http://investing.com

Gambar 16 Grafik Saham KBLI Indikator WMA dan Stochastic 
Berdasarkan grafik di atas perhatikan pada candle stick pada bulan Juli 2015 yang menunjukkan bahwa MA 5 memotong MA 10 dari sisi bawah ke atas, maka itu merupakan sinyal beli karena terjadi crossing, dan setelah itu keadaan trend menjadi naik, hal ini dapat terlihat sampai bulan Juni tahun 2019 terkonfirmasi dengan stochastic pada bulan Juli 2015 terdapat sinyal beli karena garis \% $\mathrm{K}$ memotong $\mathrm{ke}$ atas garis \%D yang berarti itu sedang dalam keadaan over sold atau jenuh jual. Kemudian, dapat diperhatikan pada gambar candle stick setelah trend naik sampai bulan Juni 2019 yang menunjukkan bahwa MA 5 memotong MA 10 dari sisi atas ke bawah, maka itu merupakan sinyal jual terjadi crossing kembali, setelah itu keadaan trend menjadi turun sampai bulan Juni 2020 terkonfirmasi dengan stochastic pada bulan Juni 2019 terdapat sinyal jual karena garis \% $\mathrm{K}$ memotong ke bawah garis \%D yang berarti itu sedang dalam keadaan Over Bought atau Jenuh Beli. Berdasarkan keterangan di atas berarti bisa kita Beli Saham KBLI pada bulan juli 2015 dan Jual pada bulan Juni 2019

\section{E. KBLM}

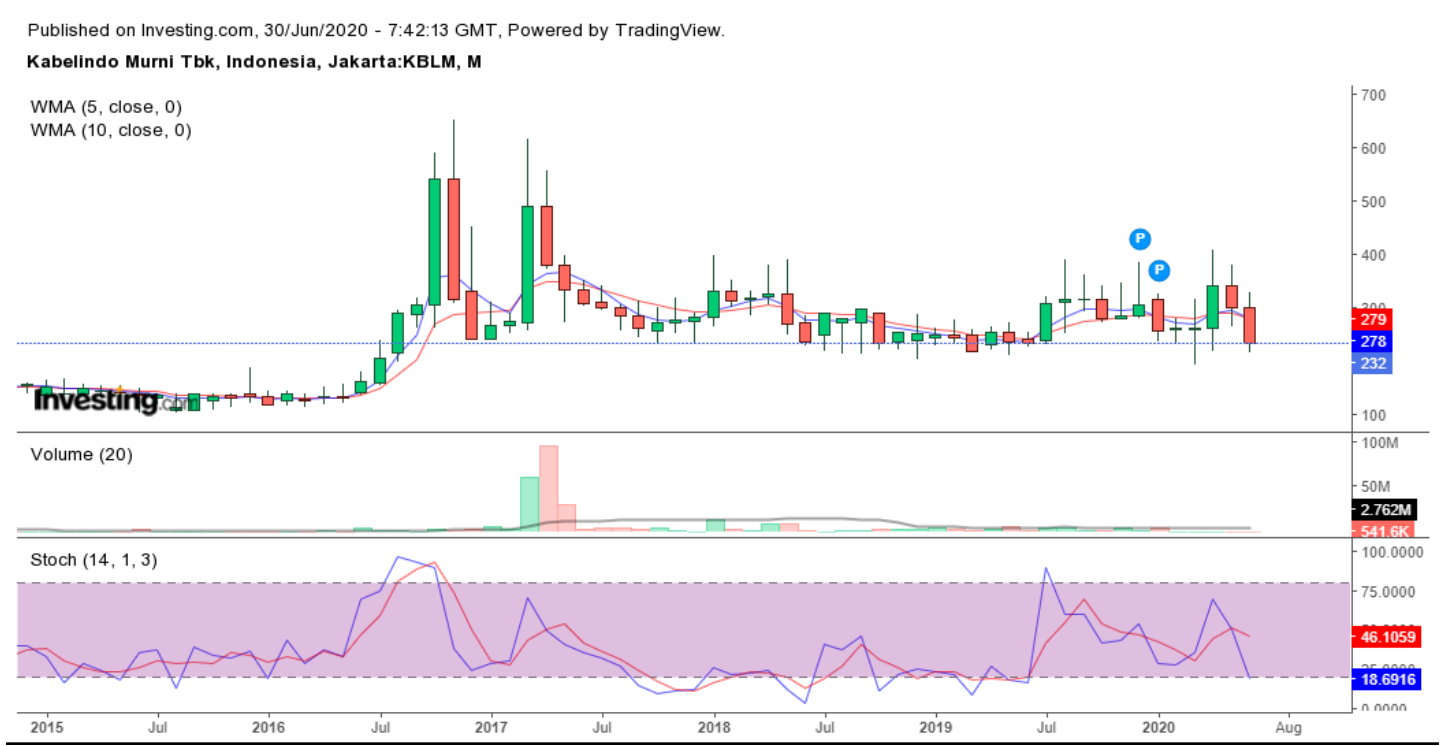

Sumber : http://investing.com

Gambar 17 Grafik Saham KBLM Indikator WMA dan Stochastic

Berdasarkan grafik di atas perhatikan pada gambar Candle stik pada awal tahun 2016 itu menunjukkan bahwa MA 5 memotong MA 10 dari sisi bawah ke atas, maka itu merupakan sinyal beli karena terjadi crossing, terkonfirmasi dengan stochastic pada awal tahun 2016 terdapat sinyal beli karena garis \% $\mathrm{K}$ memotong ke atas garis \%D yang berarti itu sedang dalam keadaan oversold atau jenuh jual. Kemudian, dapat diperhatikan pada candle stick setelah trend naik sampai bulan Juli 2016 tepatnya bulan Oktober 2018 yang menunjukkan bahwa MA 5 memotong MA 10 dari sisi atas ke bawah dan garis MA 5 menyentuh candle stick merah bulan Oktober maka itu merupakan sinyal jual terjadi crossing kembali, setelah itu keadaan trend menjadi turun sampai awal 2019 terkonfirmasi dengan stochastic pada bulan Oktober 2018 terdapat sinyal jual karena garis \% $\mathrm{K}$ memotong ke bawah garis \%D yang berarti itu sedang dalam keadaan overbought atau jenuh beli. Berdasarkan keterangan di atas, menunjukkan bahwa kita dapat membeli saham KBLM pada awal tahun 2016 dan jual pada bulan Oktober 2018

Setelah melakukan analisa kepada lima perusahaan dengan menggunakan indikator stochastic dan weighted moving average, kita dapat mengetahui kapan waktunya untuk membeli dan menjual suatu saham. 
Tahun 2020 merupakan tahun yang penuh tantangan dengan resmi dinyatakannya covid19 masuk ke Indonesia. Berdasarkan hasil analisa pergerakan harga saham kelima perusahaan pada sector aneka industri dapat dilihat bahwa saham SCCO dan KLBM pada awal tahun 2020, mengindikasikan sinyal jual, sedangkan harga saham masih dinilai undervalued. Hal ini dapat diartikan, sebaiknya investor dapat menunggu hingga secara analisa teknikal menujukkan adanya sinyal beli. Sedangkan pada saham INDR dan INDS kondisi pada saat awal tahun 2020 menunjukkan adanya sinyal beli, keputusan yang diambil adalah membeli saham tersebut. Pergerakan harga saham KBLI pada awal tahun 2020 tidak menunjukkan adanya sinya beli dan sinyal jual, sehingga sebaiknya investor wait and see atau menunggu terlebih dulu hingga muncul sinyal beli atau menunggu hingga harga saham tersebut naik untuk dijual.

\section{PENUTUP \\ Kesimpulan}

Berdasarkan hasil analisis menggunakan indikator stochastic yang menunjukan level overbought dan level oversold harga saham, saham perusahaan INDS menunjukkan sinyal jual dan sinyal beli lebih banyak dibandingkan perusahaan lain selama periode pengamatan. Dari kelima saham tersebut, hanya KLBM yang terpengaruh atas kondisi pandemic covid-19 di Indonesia. Sedangkan berdasarkan analisis dengan indiator Weighted Moving Average (WMA), saham KBLI menunjukkan sinyal jual dan sinyal beli lebih banyak dibandingkan saham perusahaan lain. Selain itu KBLI juga terlihat terpengaruh adanya pandemic covid-19 di Indonesia.

Kedua indikator stochastic oscillator dan WMA masing-masing memiliki keunikan dalam mempresentasikan pergerakan harga saham. Dari hasil analisa pergerakan kelima saham selama periode 2015-2019 dengan kedua indikator tersebut dapat dilihat bahwa kelima saham perusahaan menunjukkan sinyal jual dan beli, namun pada awal tahun 2020, sinyal yang muncul mengindikasikan untuk menjual saham, sedangkan harga saham masih murah. Hal ini menunjukkan bahwa investor dapat menunggu atau wait and see sampai pergerakan harga menujukkan adanya sinyal beli pada indikator tersebut.

\section{Saran}

Dari proses dan hasil analisis yang telah dilakukan dan untuk analisis selanjutnya, sebaiknya investor yang menggunakan analisis teknikal untuk melihat pergerakan trend, pembalikan trend, level overbought dan level oversold yang dapat digunakan sebagai dasar dalam pengambilan keputusan saat trading juga dilengkapi dengan analisis fundamental perusahaan. Analisis fundamental tetap dibutuhkan untuk mengetahui perusahaan mana yang memiliki fundamental yang baik dan cocok untuk tujuan investasi. Selanjutnya, investor juga dapat menggunakan kombinasi dari beberapa indikator teknikal lainnya, karena setiap indikator memiliki kelebihan dan keunikan masing-masing.

\section{DAFTAR PUSTAKA:}

Edusaham, Tim. (2019). Apa Itu Trendline Dalam Saham (Uptrend, Downtrend, dan Sideways), https://www.edusaham.com/2019/03/apa-itu-trendline-dalam-saham-uptrend-downtrendsideways.html. Diakses 25 Juni 2020.

Gunawan, M. A. (2013). Statistik untuk Penelitian Pendidikan. Edisi Pertama.

Jorion, P. (2007). Value at risk: the new benchmark for managing financial risk. The McGraw-Hill Companies, Inc.

http://investing.com. Diakses 29 Juni 2020 
Martia, D. Y., Setyawati, W., \& Hastuti, Y. (2018). Analisis Valuasi Saham PT. Semen Indonesia (Persero) Tbk Dengan Metode Discounted Cash Flow (DCF). Jurnal Aktual Akuntansi Keuangan Bisnis Terapan (AKUNBISNIS), 1(2).

Martia, D. Y., Wati, R., Wahyuni, M., \& Pinandhito, K. (2020). Penilaian Kewajaran Dan Pengambilan Keputusan Investasi Saham Pt Industri Jamu Dan Farmasi Sido Muncul Tbk. Jurnal Aktual Akuntansi Keuangan Bisnis Terapan (AKUNBISNIS), 3(2), 137-144.

Martin. (2013). Menggunakan Indikator Stochastic Dalam Trading Forex, https://www.seputarforex.com/artikel/menggunakan-indikator-stochastic-dalam-trading-forex138885-31. Diakses 25 Juni 2020

Naufal, F. (2018). Analisis Teknikal Pergerakan Harga Saham Individual Dengan Menggunakan Indikator Ichimoku Kinko Hyo Dan Moving Average Convergence-Divergence (MACD). Skripsi. FEBI. Universitas Islam Negeri Walisongo: Semarang.

Nugraha, A. (2018). Analisis Komparatif Penggunaan Metode Stochastic, Moving Average dan MACD dalam Mendapatkan Keuntungan Optimal Dan Syar'i (Studi Pada Jakarta Islamic Index 20142016) Comparative. Jurnal Universitas Islam Indonesia Yogyakarta.

Olsen, R. A. (1997). Investment risk: The experts' perspective. Financial Analysts Journal, 53(2), 62-66.

Sugiyono, P. D. (2010). Metode Penelitian Kuantitatif, Kualitatif \& RND. Bandung: Alfabeta.

Team, FSM. (2015). Indikator Moving Average, https://forexstarmoon.com/artikel/indikatorforex/indikator-moving-average/7466/. Diakses 25 Juni 2020

Wira, D. (2010). Analisis Teknikal untuk Profit Maksimal. Jakarta: Exceed.

Yustian, D. S., Maruddani, D. A. I., dan Hoyyi, A. (2019). Analisis Teknikal Saham dengan Indikator Gabungan Weighted Moving Averagedan Stochastic Oscillator. Jurnal gaussian, 8(1), 1-11. 